Wright State University

CORE Scholar

$3-2000$

\title{
Periphyton Production on Wood and Sediment: Substratum- specific Response to Laboratory and Whole-lake nutrient Manipulations
}

Yvonne Vadeboncoeur

Wright State University - Main Campus, yvonne.vadeboncoeur@wright.edu

David M. Lodge

Follow this and additional works at: https://corescholar.libraries.wright.edu/biology

Part of the Biology Commons, and the Systems Biology Commons

\section{Repository Citation}

Vadeboncoeur, Y., \& Lodge, D. M. (2000). Periphyton Production on Wood and Sediment: Substratumspecific Response to Laboratory and Whole-lake nutrient Manipulations. Journal of the North American Benthological Society, 19 (1), 68-81.

https://corescholar.libraries.wright.edu/biology/583

This Article is brought to you for free and open access by the Biological Sciences at CORE Scholar. It has been accepted for inclusion in Biological Sciences Faculty Publications by an authorized administrator of CORE Scholar. For more information, please contact library-corescholar@wright.edu. 


\title{
Periphyton production on wood and sediment: substratum-specific response to laboratory and whole-lake nutrient manipulations
}

\author{
YvONNE VADEBOnCOEUR ${ }^{1}$ AND DAVID M. LodGE \\ Department of Biological Sciences, University of Notre Dame, P.O. Box 369, \\ Notre Dame, Indiana 46556 USA
}

\begin{abstract}
Substratum heterogeneity is a large source of variability in periphyton production, but the influence of substratum on periphyton response to experimental manipulations is rarely measured. Using laboratory and whole-lake experiments, we compared area-specific primary production of periphyton on wood (epixylon) and sediment (epipelon), and tested whether periphyton on the 2 substrata responded differently to water-column fertilization. In the laboratory, natural periphyton assemblages on wood or sediment were exposed to 1 of 6 treatments in a fully factorial (light [250, 70 , or $10 \mu \mathrm{mol} \mathrm{m}{ }^{-2} \mathrm{~s}^{-1}$ ] $\times$ nutrient [control or $+\mathrm{N}$ and $\left.\mathrm{P}\right]$ ) experiment. We measured ${ }^{14} \mathrm{C}$ primary production on both substrata after 25 to $30 \mathrm{~d}$. We also measured epipelic and epixylic production in a reference and an experimentally fertilized lake. We constructed photosynthesis-irradiance curves for epipelon from 3 depths in each lake, and used the curves to predict primary production at average in situ light intensities for each lake and depth.

Production response to fertilization was substratum-specific, and area-specific epipelic production was $10 \times$ that of epixylon at both experimental scales. Both epixylon (ANOVA, $p<0.0001$ ) and epipelon (ANOVA, $p<0.0001$ ) production increased significantly with increasing light. Epixylon production was significantly higher in fertilized treatments than in controls (ANOVA, $p<0.01$ ), but epipelon did not respond to fertilization (ANOVA, $p=0.69$ ). Epixylon production was also significantly higher in the fertilized lake than in the reference lake (ANOVA, $p<0.05$ ). Maximum epipelic production rates decreased with water depth in both lakes, and average epipelic production from both lakes was positively and similarly related to average in situ light intensities (linear regression, $\left.R^{2}=0.94, p=0.001\right)$. Both substratum-specific response to fertilization and substratum-specific periphyton production may be critical in determining fertilization-induced changes in periphyton production in lakes.
\end{abstract}

Key words: periphyton, substratum, primary production, epipelon, epixylon, nutrients, light, lakes.

Experiments have shown conclusively that light and nutrient availability strongly affect periphyton abundance and production in freshwater ecosystems (Round 1961, Björk-Ramberg 1984, Shortreed et al. 1984, Fairchild et al. 1985, Peterson et al. 1985, 1993, Mazumder et al. 1989, Hill and Boston 1991, Bothwell 1993, Fairchild and Sherman 1993, Rosemond 1993, Rosemond et al. 1993, Hill 1996). In addition, substratum (e.g., macrophytes, rocks, sediment) affects the light and nutrient environment of associated periphyton (Sand-Jensen and Borum 1991, Burkholder 1996, Lowe 1996, Krause-Jensen and Sand-Jensen 1998). Thus, it is likely that substratum influences the response of periphyton to alterations in resource availability. However, experimental evaluation of the effect of nutrients

\footnotetext{
${ }^{1}$ Present address: Department of Biology, McGill University, 1205 Docteur Penfield Avenue, Montreal, Quebec, Canada H3A 1B1. E-mail: yvadeb@po-box.mcgill.ca
}

and light on periphyton on $>1$ natural substratum are exceedingly rare (Björk-Ramberg and Ånell 1985).

Chemical and physical properties of substrata affect periphyton primary production (Kairesalo 1980, Pringle 1990, Burkholder 1996). Rocks are not usually a nutrient source for associated algae (epilithon), but are physically stable relative to unconsolidated sediment or macrophytes. Similarly, wood is probably chemically inert with respect to $\mathrm{N}$ and $\mathrm{P}$, but few studies have considered epixylic algae (Sinsabaugh et al. 1991, Couch and Meyer 1992, Scholz and Boon 1993). Other substrata are nutrient sources for periphyton. Macrophytes leak nutrients to epiphytes (Burkholder and Wetzel 1990). Periphyton growing on unconsolidated organic sediment (epipelon) and sand and gravel sequester nutrients from pore water and groundwater (Carlton and Wetzel 1988, Hansson 1988, 1989, 1990, Hagerthey and Kerfoot 1998). There is also evidence that periphyton on non-nutrient dif- 
fusing substrata have high biomass accumulation when placed close to organic sediment, suggesting that the effect of sediment nutrients on periphyton extends short distances from the sediment-water interface (Blumenshine et al. 1997). Thus, the response of periphyton on a given substratum to water-column $\mathrm{N}$ and $\mathrm{P}$ additions may depend on whether the water column, the substratum, or the sediment pore water is the primary nutrient source (Sand-Jensen and Borum 1991).

Different substrata are associated with light availability because abundance of different substrata is usually related to water depth (Lowe 1996). Nonrandom distributions of substrata with respect to depth, and therefore light, result from particle sorting. Because they are essentially sessile, periphyton assemblages experience a limited range of light intensities dependent on the water depth at which the substratum occurs. Rocks are common substrata at the edge of lakes where they are kept free from fine sediment by waves and ice scour. Large wood is often anchored in the riparian zone, and is also typically limited to shallow littoral areas. Thus, abundance of exposed rocks and wood will typically decrease with increasing watercolumn depth, and most periphyton associated with these substrata occur in the well-lit, shallow littoral zone. In contrast, fine sediment, especially organic sediment, settles into deeper areas of the lake and areas where water motion is reduced (Hilton 1985, Hilton et al. 1986, James and Barko 1990, Rasmussen and Rowen 1997). Epipelon is expected to be the most common periphyton assemblage in deep and dark areas of the lake.

Periphyton response to fertilization may depend on in situ light conditions. For example, periphyton in an oligotrophic stream responded to nutrient enrichment at high, but not low, light levels (Hill and Knight 1988). Algae have high cellular nutrient requirements at suboptimal light intensities (Wynne and Rhee 1986, Borchardt 1996). Thus, the fertilization growth-response of periphyton on non-nutrient diffusing substrata such as rocks or wood may be small at very low light and increase along a gradient of increasing light. The limited evidence suggests that epipelic algae exhibit nutrient limitation only in very oligotrophic systems where light availability is high (Stanley 1976, Hansson 1992). Thus, substratum and its distribution with respect to depth and light may affect the intensity of the response of natural periphyton assemblages to alterations in water-column nutrients.

We isolated defaunated periphyton assemblages on wood and sediment in the laboratory, and exposed them to 3 light $\times 2$ nutrient levels for 25 to $30 \mathrm{~d}$ to assess the impact of substratum on periphyton productivity. We tested: 1 ) if substratum influenced whether periphyton production increased as a result of water-column fertilization; 2) if periphyton response to nutrient addition increased with increasing light intensity; and 3) if pore-water nutrients were transferred to the water column and became available to primary producers growing near, but not on, sediment. We also concurrently compared epixylic production and epipelic photosynthesis-irradiance (P-I) response curves in a reference and an experimentally fertilized lake. The wholelake experiment allowed us to determine whether periphyton responses to fertilization in the controlled laboratory experiment were indicative of periphyton responses when natural densities of grazers were present and at natural light and temperature levels.

\section{Methods}

\section{Study sites}

Paul Lake (reference, $1.7 \mathrm{ha}, \mathrm{z}_{\max }=12 \mathrm{~m}$ ) and West Long Lake (fertilized, 3.4 ha, $z_{\max }=17.7$ m) are oligotrophic soft-water lakes at the University of Notre Dame Environmental Research Center (UNDERC) (lat $46^{\circ} 13^{\prime} \mathrm{N}$, long $89^{\circ} 32^{\prime} \mathrm{W}$ ) in upper Michigan, USA. They are 2 of 6 basins at UNDERC that are part of the Cascading Trophic Interactions Project (Carpenter and Kitchell 1993, Carpenter et al. 1995, 1996, 1998, Christensen et al. 1996). Paul Lake is the reference lake for the project and was not manipulated during this study.

During the summers of 1993 to 1995, West Long Lake was fertilized daily with $\mathrm{N}$ and $\mathrm{P}$ (N:P $>25: 1$ by atoms), and fertilization caused phytoplankton blooms in all years. Summer average $\mathrm{P}$ addition rates were $1.43 \mathrm{mg} \mathrm{m}^{-3} \mathrm{~d}^{-1}$ in 1993, $0.86 \mathrm{mg} \mathrm{m}^{-3} \mathrm{~d}^{-1}$ in 1994, and $0.40 \mathrm{mg} \mathrm{m}^{-3}$ $\mathrm{d}^{-1}$ in 1995. Background $\mathrm{P}$ loading was $\sim 0.15$ $\mathrm{mg} \mathrm{m}^{-3} \mathrm{~d}^{-1}$ (Carpenter et al. 1996). Dissolved N accumulated in the fertilized lake, but dissolved P did not (S. R. Carpenter, University of Wis- 
consin, Madison, unpublished data). Phytoplankton response was closely correlated with P input rate (Carpenter et al. 1996, Cottingham and Carpenter 1998), and for simplicity, we used $\mathrm{P}$ loading alone as an index of fertilization rate. We did not test $\mathrm{N}$ versus $\mathrm{P}$ limitation, and do not intend to imply that $\mathrm{P}$ rather than $\mathrm{N}$ limited periphyton production.

Wood and sediment are the only abundant benthic substrata in the 2 lakes. The lake peripheries are wooded, and woody debris is present down to $4 \mathrm{~m}$ water depth. However, most wood is large downed trees, and occurs between the lake edge and $1.0 \mathrm{~m}$ water depth. Substratum in the littoral zone of both lakes is dominated by soft organic sediment, which composes $>80 \%$ of benthic surface area from the lake edge to $7 \mathrm{~m}$ water depth. The sediment is flocculent ( $95 \%$ water by weight) and organic (40-60\% dry mass). Thermocline depth in both lakes is typically $3 \mathrm{~m}$, but photosynthesizing epipelic algal mats are present to $7 \mathrm{~m}(<0.5 \%$ light). Epilimnetic epipelic assemblages formed a thick $(\sim 10 \mathrm{~mm})$ mucilaginous matrix with the sediment that consisted of pennate diatoms, single-celled chlorophytes, and filamentous and colonial cyanobacteria. Metalimnetic epipelic assemblages were dominated by motile filamentous cyanobacteria and motile diatoms that formed a thin mat $(\sim 1 \mathrm{~mm})$ that lay over the surface of the sediment. Colonial cyanobacteria and filamentous chlorophytes dominated epixylon assemblages (Y. Vadeboncoeur and D. M. Lodge, unpublished data).

\section{Factorial light $\times$ nutrient laboratory experiment}

We incubated periphyton assemblages in $19 \mathrm{~L}$ (35 cm high $\times 22.5 \mathrm{~cm}$ diameter) white plastic buckets in a fully factorial (3 light $\times 2$ nutrient) laboratory experiment. Each bucket contained 1 natural substratum, either wood or sediment. We minimized phytoplankton shading by leaving only 20 to $30 \mathrm{~cm}$ of water above the substratum. Buckets were placed under metal halide lamps (Sylvania Metal Arc MP, 400 W) on a 14:10 h light:dark cycle. We used neutral density shade cloth to create light treatments of 250, 70 , and $10 \mu \mathrm{mol} \mathrm{m} \mathrm{m}^{-2} \mathrm{~s}^{-1}$. Half of the replicates in each light treatment were unfertilized controls. The remaining replicates were fertilized daily with a solution of $\mathrm{NH}_{4} \mathrm{NO}_{3}$ and $\mathrm{Na}_{2} \mathrm{HPO}_{4}$ (N:P 9:1 by atoms). It was only possible to run
3 replicates of each treatment for each substratum at 1 time because of time and equipment constraints. Therefore, we blocked the experiment in time (Sokal and Rohlf 1981) to increase statistical power. In 1993, we ran 2 consecutive blocks (14 July-8 August, 13 August-7 September), and we added fertilizer at a rate of $1 \mathrm{mg}$ $\mathrm{P} \mathrm{m}^{-3} \mathrm{~d}^{-1}$. In 1994, we ran only 1 block (6 August-5 September), and we increased the nutrient load to $2 \mathrm{mg} \mathrm{m}^{-3} \mathrm{~d}^{-1}$ to correspond to maximal loading rates in the whole-lake experiment and a previous mesocosm experiment (Blumenshine et al. 1997, Cottingham et al. 1997). A planned 2nd block in 1994 was not run, and fertilization rates were not replicated within blocks. Therefore, we could not test the effect of the change in fertilization rate between years, and simply compared fertilized versus unfertilized treatments in the analysis.

We collected naturally occurring wood visibly colonized with periphyton from $\sim 1 \mathrm{~m}$ water depth in the reference lake. A snorkeler used pruning shears to cut branches $(\sim 3 \mathrm{~cm}$ diameter) from submerged trees with minimal disturbance. We cut the wood into $20 \mathrm{~cm}$ lengths, and placed 2 pieces of wood (combined surface area $\sim 0.04 \mathrm{~m}^{2}$ ) into each of 18 buckets. Each bucket contained $15 \mathrm{~L}$ of reference-lake water that had been filtered through a $150-\mu \mathrm{m}$ net to remove large zooplankton. We then added ABATE insecticide $\left(\mathrm{O}, \mathrm{O}^{\prime}\right.$-(thiodi-4,1-phenylene) bis $(\mathrm{O}, \mathrm{O}$ dimethly phosphorothiate); $5 \mathrm{mg} / \mathrm{L}$ ) to defaunate the periphyton. Following a 24-h exposure (after which visual inspection indicated high macroinvertebrate mortality and no apparent effect on periphyton), we replaced the water with filtered reference-lake water. We randomly assigned each container to a treatment.

We collected sediment from the reference lake at a water depth of $1.5 \mathrm{~m}$ using a corer with the same dimensions as the experimental buckets. A SCUBA diver pushed the corer $10 \mathrm{~cm}$ into the sediment and isolated the sediment core by inserting a slide into a slit near the bottom of the corer. The sediment was then transferred immediately to an experimental bucket. Some disturbance of the sediment was inevitable during collection. Therefore, for $1 \mathrm{wk}$ after collection, the cores were left undisturbed in the laboratory under ambient lake light conditions $(250 \mu \mathrm{mol}$ $\mathrm{m}^{-2} \mathrm{~s}^{-1}, 14: 10 \mathrm{~h}$ light:dark cycle). After $1 \mathrm{wk}$, we added ABATE to the water overlying the sediment. After $24 \mathrm{~h}$ of exposure to the insecticide, 
we replaced the water with $12 \mathrm{~L}$ of filtered lake water. Each bucket contained sediment $\left(0.04 \mathrm{~m}^{2}\right.$ surface area $\times 10 \mathrm{~cm}$ deep) covered with $20 \mathrm{~cm}$ of water.

The experiment began the day after the water was replaced. We added nutrients to the water in the fertilized treatments each morning and then gently stirred the water in all buckets. Air was bubbled constantly into each container to maintain gentle water circulation. A glass slide $(22 \times 75 \mathrm{~mm})$ was suspended from the water surface in each container to test for local effects of substratum on primary producers growing near, but not on, the substratum. We were particularly interested in whether sediment porewater nutrients were released to the overlying water and became available to adjacent primary producers, and how the magnitude of this effect compared with the effect of water-column fertilization on glass-slide chlorophyll.

We measured ${ }^{14} \mathrm{C}$ primary production at the end of each block. We used area-specific, rather than biomass-specific, production rates. Differences in chlorophyll, the most common index of algal biomass, can be difficult to interpret when light is an experimental variable because the cellular chlorophyll content of periphyton tends to increase in response to reduced light (Falkowski and LaRoche 1991). Also, undegraded chlorophyll and inactive algal cells below the zone of active photosynthesis in epipelic mats make it difficult to distinguish between photosynthetically active and inactive algal biomass (SandJensen and Revsbech 1987, Pinckney and Zingmark 1993, Hill et al. 1995).

There are no standard methods for measuring epixylon primary production, but we used the guidelines suggested by Pregnall (1991) for periphyton on rocks. Two sections (each $\sim 20 \mathrm{~mm}$ long) of a single piece of wood from each container were isolated in cylindrical chambers (1 light, 1 dark; $75 \mathrm{~mm} \times 35 \mathrm{~mm}$ ID) constructed from clear Plexiglas (Vadeboncoeur and Lodge 1998). We added $7.4 \mathrm{Kbq}$ of ${ }^{14} \mathrm{C}$ (aqueous $\mathrm{NaH}^{14} \mathrm{CO}_{3}{ }^{-}$) to each chamber immediately before light incubation. After a 2-h incubation at experimental light intensities, we moved the wood to the dark and subsampled the water in each chamber. ${ }^{14}$ Carbon activity in these water samples was measured on a Beckman LS 5000 TD liquid scintillation counter with external quench correction.

In 1993, wood sections were immediately fro- zen and freeze-dried. We then brushed the freeze-dried periphyton from the wood, suspended it in deionized water, and collected it on membrane filters (Nuclepore MF, 0.45- $\mu \mathrm{m}$ pore size). We rinsed material remaining on the brush and wood onto the filter. Freeze-drying apparently maintained the structural integrity of the periphyton, the material was retained on the filters, and the filtrate was clear. In 1994, we switched to a more common protocol used for periphyton on rocks. Periphyton was brushed from the wood and suspended in water immediately after incubation. The suspension was then filtered onto a glass-fiber filter (Whatman $\mathrm{GF} / \mathrm{F}$, nominal pore size $0.7 \mu \mathrm{m}$ ). In both years, filters were placed in scintillation vials, dried at $55^{\circ} \mathrm{C}$, and fumed over $\mathrm{HCl}$ for $10 \mathrm{~min}$. We then added $10 \mathrm{~mL}$ scintillation fluor to each vial and measured ${ }^{14} \mathrm{C}$ activity. Dissolved inorganic carbon (DIC) in the buckets was measured as $\mathrm{CO}_{2}$ evolved upon acidification using a gas chromatograph (Stainton et al. 1977). We subtracted dark uptake and calculated primary production per unit wood surface area (Pregnall 1991).

We measured ${ }^{14} \mathrm{C}$ epipelic primary production following the methods of Revsbech et al. (1981) as modified by Vadeboncoeur and Lodge (1998). Two intact cores (1 light and 1 dark, $2 \mathrm{~cm}$ of sediment $+2 \mathrm{~cm}$ overlying water) were removed from each bucket without disrupting the algal mat. We used the same production chambers as for wood. After adding $7.4 \mathrm{Kbq}$ of ${ }^{14} \mathrm{C}$ to each sediment core, we placed the cores in the dark for $2 \mathrm{~h}$ to allow equilibration of ${ }^{14} \mathrm{C}$ between the overlying and interstitial water. A 2-h incubation at experimental light intensities followed the equilibration period. Cores were then processed immediately, freeze dried, and a 5-mg subsample was counted on the Beckman LS 5000 TD liquid scintillation counter (Vadeboncoeur and Lodge 1998).

The glass slides suspended in the buckets were collected and frozen at the end of each block. We collected water samples from the buckets and filtered them (Whatman GF/F) for phytoplankton chlorophyll analysis in 1993 only. Slides and filters were extracted in $100 \%$ methanol for $24 \mathrm{~h}$ and the extract was analyzed fluorometrically for phaeophyton-corrected chlorophyll $a$ (Holm-Hansen 1978, Marker et al. 1980). We collected and froze water samples from each bucket at the end of each block and 
measured water-column total $\mathrm{P}$ concentration ([TP]) on a Lachat autoanalyzer.

All data from the laboratory experiment were log-transformed to conform to the assumptions of ANOVA (Zar 1996). We used SYSTAT computer software for Windows (version 7.0, SYSTAT Inc., Evanston, Illinois). We 1st ran an ANOVA to test for a substratum effect on primary production. We then ran separate ANOVAs for primary production on wood and sediment with light and nutrients as factors. We included a blocking factor, but did not include interactions between blocks and factors because block was a random effect that was entirely a concession to time and space limitations. We had no a priori expectation that the time at which the experiments were run would affect substratumspecific responses to nutrients. We were interested in the presence or absence of such an affect, not variation in its magnitude over time (see Newman et al. 1997). We also used ANOVA to test for treatment effects on phytoplankton chlorophyll, glass-slide chlorophyll, and watercolumn [TP]. Again, we 1st tested for a substratum effect and then ran separate ANOVAs for each substratum to test for nutrient and light effects.

\section{Whole-lake fertilization experiment}

In August 1995, we collected wood from 0.5 $\mathrm{m}$ water depth in the fertilized and reference lakes. This epixylon ( 3 light and 3 dark for each lake) was incubated under metal halide lamps at $450 \mu \mathrm{mol} \mathrm{m} \mathrm{m}^{-2} \mathrm{~s}^{-1}$ for $2 \mathrm{~h}$. Average summer irradiance at $0.5 \mathrm{~m}$ was $600 \mu \mathrm{mol} \mathrm{m}^{-2} \mathrm{~s}^{-1}$ in the reference lake and $515 \mu \mathrm{mol} \mathrm{m} \mathrm{m}^{-2} \mathrm{~s}^{-1}$ in the fertilized lake. It was difficult to produce uniform light intensities $>450 \mu \mathrm{mol} \mathrm{m} \mathrm{m}^{-2} \mathrm{~s}^{-1}$ with our lamps, but photosynthesis was probably near light-saturated rates at that intensity (Hill 1996). We processed the wood as described for the 1994 laboratory experiment. We log-transformed the production estimates and used ANOVA to compare the 2 lakes.

We monitored the response of epipelon to whole-lake fertilization by comparing P-I curves from the 2 lakes. Using SCUBA, and without disrupting the epipelic mat, we collected 15 to 20 intact sediment cores (Vadeboncoeur and Lodge 1998) at each of 3 depths in each lake. On 26 August 1993, we collected cores from Paul Lake at $1.5,2.5$, and $4.5 \mathrm{~m}\left(22^{\circ} \mathrm{C}, 22^{\circ} \mathrm{C}\right.$, and $12^{\circ} \mathrm{C}$, respectively), which corresponded to the upper epilimnion, the lower epilimnion, and the upper metalimnion. On 29 August 1994, we collected cores from corresponding thermal strata of West Long Lake $\left(1.5,2.5\right.$, and $5.2 \mathrm{~m} ; 19^{\circ} \mathrm{C}, 19^{\circ} \mathrm{C}$, and $12^{\circ} \mathrm{C}$, respectively). We constructed an additional P-I curve for the lower epilimnion of Paul Lake $\left(2.5 \mathrm{~m}, 24^{\circ} \mathrm{C}\right)$ on 14 August 1995. We added ${ }^{14} \mathrm{C}$ as described above for sediment, and then incubated all cores in the laboratory in water baths under the lamps used for the laboratory experiments. During the 2-h incubations, the cores were maintained at the temperature $\left( \pm 1^{\circ} \mathrm{C}\right)$ at which they were collected. We used neutral density shade cloth to create light intensities ranging from 5 to $375 \mu \mathrm{mol} \mathrm{m} \mathrm{m}^{-2} \mathrm{~s}^{-1}$. We terminated incubations by placing all cores in the dark and immediately processed them (Vadeboncoeur and Lodge 1998). After calculating areal primary production $\left(P^{A}\right)$ we used nonlinear regression (SYSTAT, procedure NONLIN) to solve for $\alpha$ and $P_{\text {max }}^{A}$ in the P-I equation (Henley 1993, Kirk 1994):

$$
P^{A}=\frac{P^{A}{ }_{\max } \alpha I}{\sqrt{\left(P^{A}{ }_{\max }\right)^{2}+\alpha^{2} I^{2}}}
$$

where $P^{A}{ }_{\text {max }}$ is the maximum areal light-saturated photosynthetic rate (i.e., the asymptote of the P-I curve), $\alpha$ is the rate of increase of photosynthesis at light-limiting irradiances (i.e., the initial slope of the P-I curve), and $I$ is light intensity $\left(\mu \mathrm{mol} \mathrm{m} \mathrm{m}^{-2} \mathrm{~s}^{-1}\right)$.

We wanted to test for a fertilization effect on epipelic algae while controlling for differences in light intensity between lakes, depths, and years. A strong positive fertilization effect would have resulted in consistently higher epipelic production in the fertilized relative to the reference lake for any given light intensity. We used the P-I equations generated by equation 1 to estimate average epipelic production at each depth for $7 \mathrm{~d}$ before and $7 \mathrm{~d}$ (inclusive) after we ran the P-I experiments. We estimated light intensity at depth $\left(I_{z}\right)$ according to the equation (Kirk 1994):

$$
I_{z}=I_{0} e^{-K_{d} z}
$$

where $I_{0}$ is surface irradiance, $K_{d}$ is the watercolumn light-attenuation coefficient, and $z$ is depth. Total daily incident radiation was measured continuously with a pyrheliometer, and $K_{d}$ was measured weekly (Carpenter et al. 1993). We used total daily incident radiation to esti- 
mate $I_{0}$ at 15 -min intervals through the day by assuming that surface light intensity varied as a sine function from sunrise to sunset (McBride 1992). $I_{z}$ was calculated and then used in the PI equations to estimate primary production at 15-min intervals throughout each day of the 2wk period bracketing the P-I measurements. We calculated average rates for each day, and finally an average rate for the 2 -wk period $\left(\mathrm{mg} \mathrm{C} \mathrm{m}^{-2}\right.$ $\mathrm{h}^{-1}$ ). The calculated rates were for daylight hours only (i.e., we did not sum over a $24-\mathrm{h}$ period that included 0 values for hours of darkness). We used regression analysis (SYSTAT, procedure GLM) to determine the relationship between average primary production predicted by the P-I curves and average light intensity at each site during the 2-wk period.

Water-column nutrient concentrations were measured weekly at stations in the middle of each lake during the whole-lake fertilization experiment (Carpenter et al. 1995, 1996). In addition, in August 1994, we collected sediment pore water and the water immediately overlying the sediment at 1-m depth intervals $(z=1.0-5.0$ $\mathrm{m})$ from the 2 lakes. A SCUBA diver collected water from immediately above $(\leq 1 \mathrm{~cm})$ the sediment-water interface using $60 \mathrm{~mL}$ syringes with flexible tubing attached to the tip. She then collected a sediment core with a PVC pipe (20 $\mathrm{cm} \mathrm{H} \times 5.1 \mathrm{~cm} \mathrm{ID)}$. The interstitial water was separated from the sediment by centrifuging the top $1 \mathrm{~cm}$ of sediment under mineral oil. The mineral oil prevented exposure to atmospheric oxygen, which might otherwise have resulted in precipitation of soluble $\mathrm{P}$ from potentially anoxic sediments (Revsbech et al. 1981). Water samples were either frozen immediately ([TP]) or filtered (Whatman GF/F) and then frozen (soluble reactive phosphorus, SRP). All P concentrations were measured on a Lachat autoanalyzer. We ran separate ANOVAs on [TP] and [SRP] for each lake. We used Tukey's HSD posthoc comparison of means to test whether P concentrations differed among the interstitial water, the water overlying the sediment, and the water column.

\section{Results}

\section{Factorial light $\times$ nutrient laboratory experiment}

Epixylon primary production increased with increasing light, and was higher in fertilized
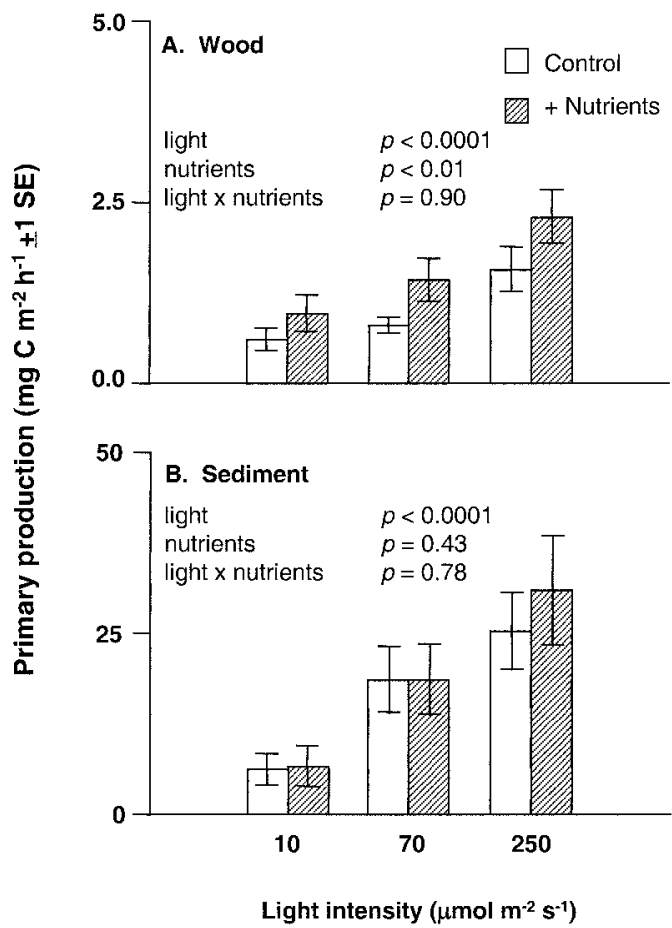

FIG. 1. Primary production on wood (A) and sediment (B) in the factorial laboratory experiments. Bars are geometric means, and the results of all 3 blocks are pooled.

containers than in the controls (Fig. 1A). There was no interaction between light and nutrients. Epipelic production increased significantly with increasing light, but the effect of fertilization was not significant (Fig. 1B). There was no significant light $\times$ nutrient interaction in epipelic production.

Substratum affected productivity of natural periphyton assemblages, glass-slide chlorophyll, phytoplankton chlorophyll, and water-column [TP]. Areal production of epipelon was consistently $10 \times$ areal production of epixylon $\left(F_{1,103}=\right.$ 253.3, $p<0.0001$, Fig.1). Glass-slide chlorophyll $\left(F_{1,103}=61.8, p<0.0001\right)$, phytoplankton chlorophyll $\left(F_{1,69}=37.58, p<0.0001\right)$, and watercolumn [TP] $\left(F_{1,95}=20.0, p<0.0001\right)$ were significantly higher in buckets containing sediment than in those with wood. Nutrient addition led to significantly higher phytoplankton and glassslide chlorophyll in buckets containing wood, but not in those with sediment (Fig. 2A, 2B). Water-column [TP] was significantly higher in fertilized treatments than in controls for both 

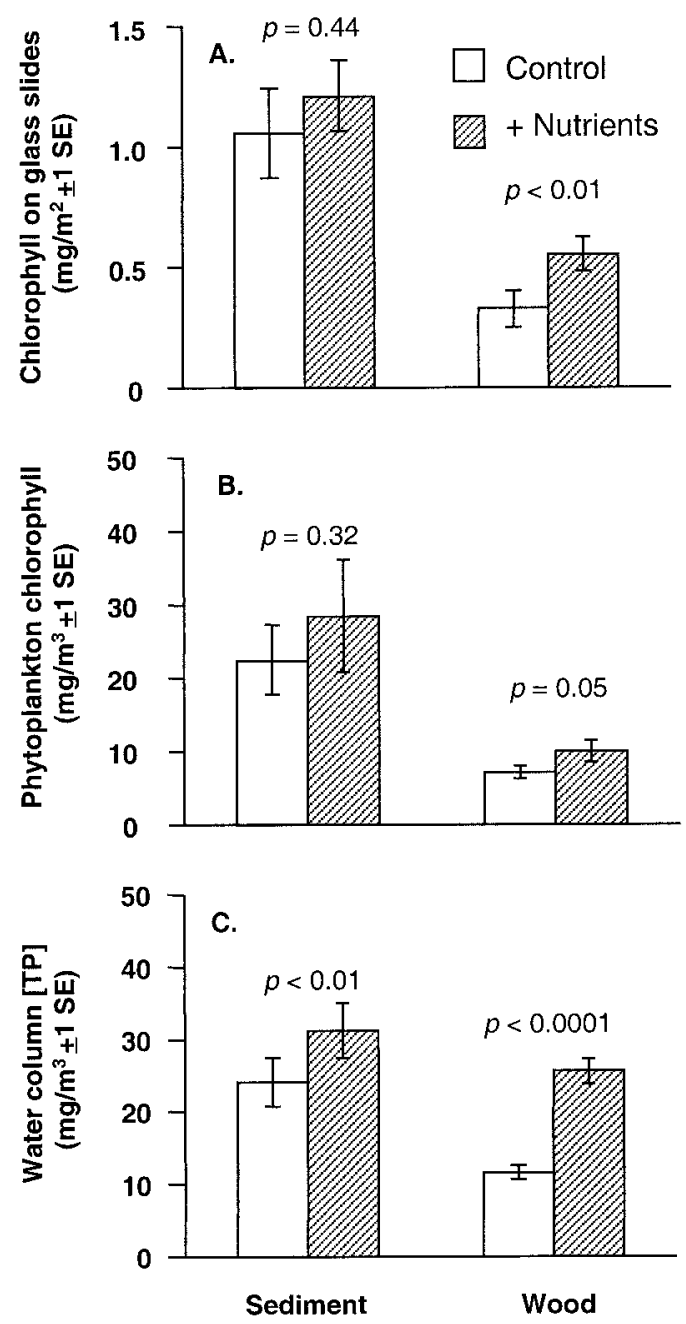

FIG. 2. Chlorophyll $a$ on glass slides (suspended in the buckets) (A), phytoplankton chlorophyll (measured only in 1993) (B), and water-column total P concentration ([TP]) (C) in the laboratory experiment. Bars are geometric means pooled over all light treatments. The $p$-values refer to an ANOVA for a fertilization effect.

substrata (Fig. 2C). Glass-slide chlorophyll was not significantly related to light (sediment: $F_{2,46}$ $=1.64 ; p=0.21$; wood: $F_{2,45}=2.16, p=0.13$ ). Both phytoplankton chlorophyll and water-column [TP] increased with light in buckets with sediment (phytoplankton: $F_{2,28}=12.51, p<$ 0.0001; [TP]: $\left.F_{2,41}=21.4, p<0.0001\right)$, but not in those with wood (phytoplankton: $F_{2,29}=0.66, p$ $=0.53$; [TP]: $F_{2,42}=1.39, p=0.26$ ).

\section{Whole-lake fertilization experiment}

Average epixylon production (measured at $450 \mu \mathrm{mol} \mathrm{m} \mathrm{m}^{-2} \mathrm{~s}^{-1}$ ) was significantly higher in the fertilized lake $\left(4.2 \mathrm{mg} \mathrm{C} \mathrm{m}^{-2} \mathrm{~h}^{-1}\right)$ than in the reference lake (1.3 $\mathrm{mg} \mathrm{C} \mathrm{m}^{-2} \mathrm{~h}^{-1} ; F_{1,2}=12.85, p$ $<0.05$ ).

Epipelon in $1.5 \mathrm{~m}$ cores did not reach maximum light-saturated photosynthesis rates in either the fertilized or reference lake (Fig. 3A, 3D). In contrast, algae from depths $>1.5 \mathrm{~m}$ became light-saturated at relatively low light levels. Epipelic production increased over the entire range of light intensities the algae experienced during the summer, except in the fertilized lake at 2.5 m (Fig. 3). To detect a fertilization effect, we used the 7 P-I curves to predict average epipelic production for each lake and depth. Predicted production at ambient in situ light intensities increased consistently with light intensity $\left(R^{2}=\right.$ 0.94, $p=0.001$, Fig. 4).

[TP] and [SRP] were significantly higher in the interstitial water than in the water column in both lakes (Fig. 5). Phosphorus concentrations in the water overlying the sediment were usually intermediate between the other 2 sources, and were not consistently different from interstitial-water or water-column concentrations.

\section{Discussion}

\section{Substratum-specific response to fertilization}

Periphyton response to fertilization was substratum-specific. Epixylon production was significantly greater in fertilized treatments than controls in both the laboratory and whole-lake experiments, indicating that water-column nutrient concentrations substantially affected epixylon production. Biomass of epilithon and algae on artificial substrata is similarly limited by water-column nutrients in other lakes and streams (Shortreed et al. 1984, Peterson et al. 1985, 1993, Cattaneo 1987, Marks and Lowe 1993). Although we know of no similar studies of primary production on natural wood, our results support the speculation that wood, like rock, is an inert substratum for periphyton with regard to $\mathrm{N}$ and P (Burkholder 1996). Other studies have indicated that wood may be a significant C source for epixylic algae, via decomposition by fungi and bacteria (Sinsabaugh et al. 1991, Sholz and Boon 1993). Our experimental design 


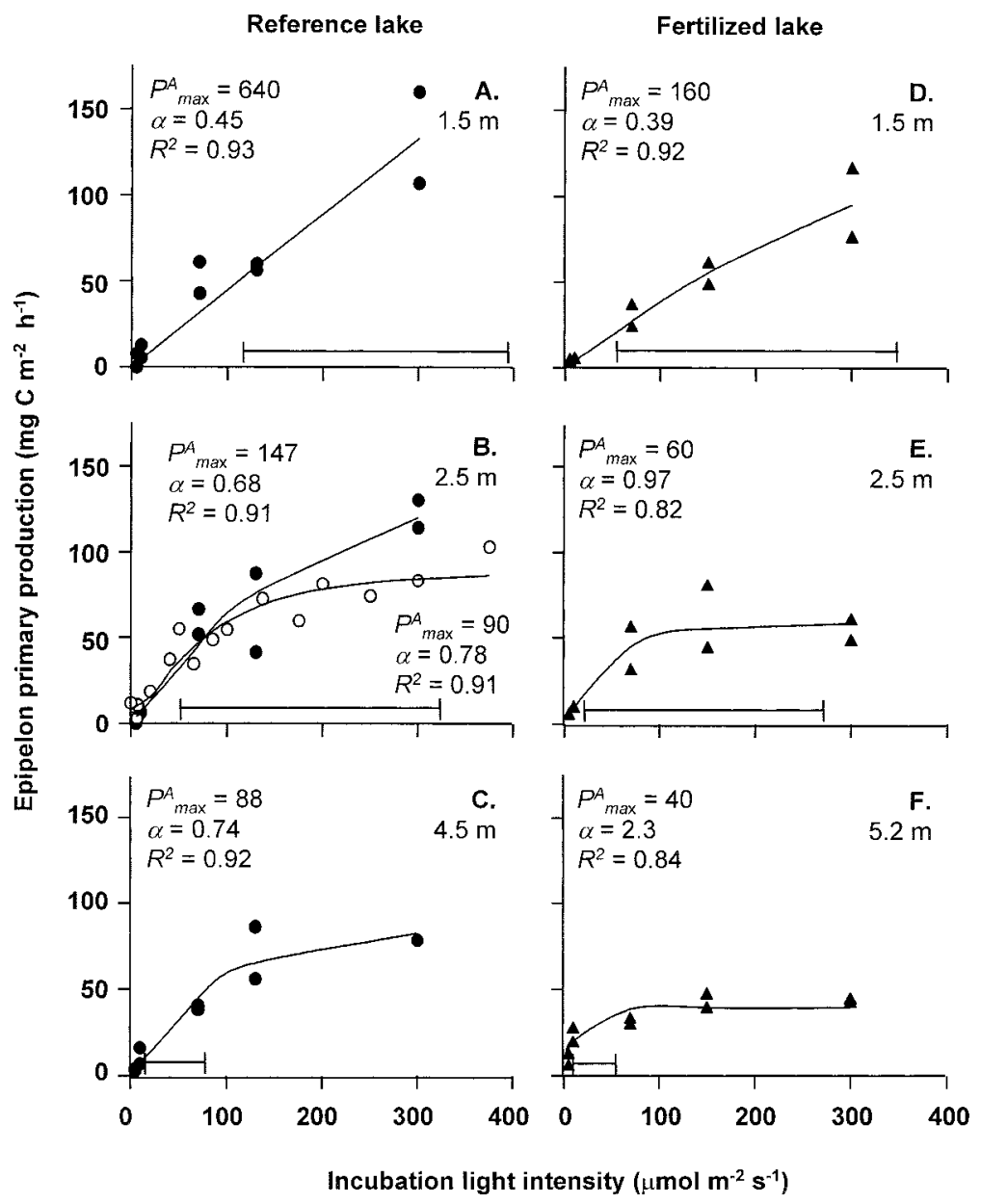

FIG. 3. Photosynthesis-irradiance (P-I) curves for epipelon from the reference (A, B, C) and fertilized (D, E, F) lakes. Depths are shown for each curve. In the reference lake, P-I curves were run for 3 depths in $1993(\bullet)$ and for $2.5 \mathrm{~m}$ only in 1995 (०). P-I curves were run only in 1994 in the fertilized lake (A). Each point represents a single core. $P_{\max }^{A}=$ maximum areal light-saturated photosynthesis $\left(\mathrm{mg} \mathrm{C} \mathrm{m} \mathrm{m}^{-2} \mathrm{~h}^{-1}\right), \alpha=$ rate of increase in photosynthesis at light-limiting irradiances (the initial slope of the P-I curve). $R^{2}$ refers to fit of the lines to equation 1. Lines along the x-axes denote the range of maximum daily light intensities during the summer months for each lake and depth.

did not allow us to test for a $C$ response, but our experiments clearly indicated that water-column $\mathrm{N}$ and $\mathrm{P}$ fertilization stimulated epixylic production.

In contrast to epixylon, water-column fertilization caused no increase in epipelic production in the laboratory (Fig. 1). In buckets with sediment, there was no difference in phytoplankton chlorophyll between fertilized and unfertilized treatments (Fig. 2). Therefore, the lack of a fertilization response for epipelon was not a result of increased shading by phytoplankton in the fertilized treatments. Epipelic production rates were also similar in the fertilized and unfertilized lakes when we corrected for differences in average in situ light availability (Fig. 4). Although epipelic algae sometimes respond positively to water-column fertilization in very shallow ecosystems (Stanley 1976, Nilsson et al. 1991), increased water-column $\mathrm{N}$ and $\mathrm{P}$ loading did not increase epipelic production in our lakes or even in the shallow buckets where shading by phytoplankton was minimal. This lack of response is consistent with interstitial water being 


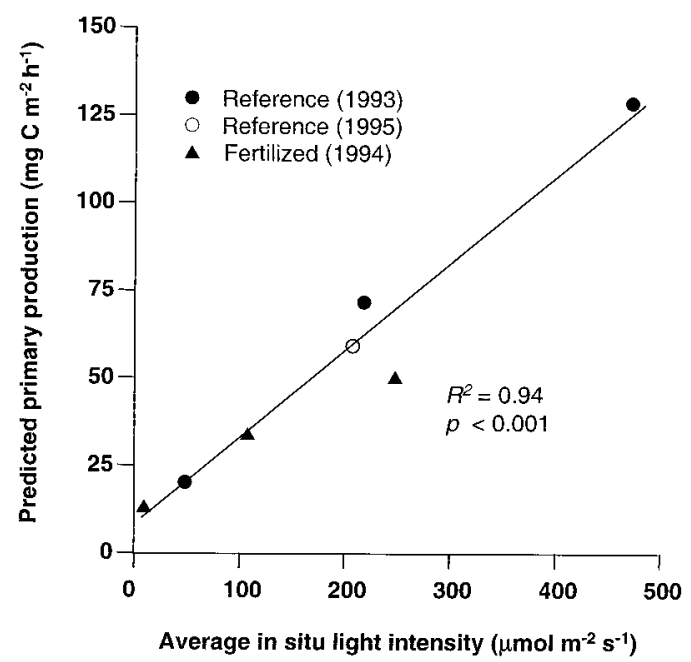

FIG. 4. Primary production of epipelic algae at average summer in situ light intensities as predicted by photosynthesis-irradiance curve equations in Fig. 3. Statistics refer to linear regression of primary production on light intensity.

the primary nutrient source for epipelic algae. Both [TP] and [SRP] were significantly higher in the pore water than in the water column in both the fertilized and reference lake (Fig. 5). This pattern is common, and periphyton on sediment can sequester these pore-water nutrients (Schindler et al. 1987, Carlton and Wetzel 1988, Hansson 1988, 1989, 1990, Reuter and Axler 1992, Hagerthey and Kerfoot 1998).

Substratum affected overall periphyton productivity and its response to fertilization. Areaspecific primary production rates of periphyton on sediment were $10 \times$ those on wood in both laboratory and whole-lake experiments. Benthic primary production in an arctic lake showed similar patterns (Welch and Kalff 1974). Areaspecific epipelic production in Char Lake was $4 \times$ higher than that of epilithon, even though epipelic assemblages grew at greater depths than epilithon. Our epipelic production rates were within the range of literature values (Wetzel 1983), whereas epixylon production was similar to epilithic production in oligotrophic lakes (Schindler et al. 1973, Loeb et al. 1983). Thus, the large differences in areal rates among substrata that we observed may be common.

\section{Influence of light}

Periphyton production on wood increased with increasing light in the laboratory experi- ment. The lack of a light $\times$ nutrient interaction for the log-transformed data indicated that the relative increase in epixylon production in response to fertilization was similar for all light treatments (Fig. 1). We had expected no fertilization response at very low light $\left(10 \mu \mathrm{mol} \mathrm{m}^{-2}\right.$ $\mathrm{s}^{-1}$ ) and an increasing response with increasing light intensity. One possible explanation for the lack of an interaction is that increased shading by phytoplankton in the buckets exposed to high light reduced the response of epixylon to fertilization. However, there was no significant light effect on phytoplankton chlorophyll in buckets with wood, so this explanation is unlikely. We did not measure epixylon biomass, but we saw an obvious increase in development

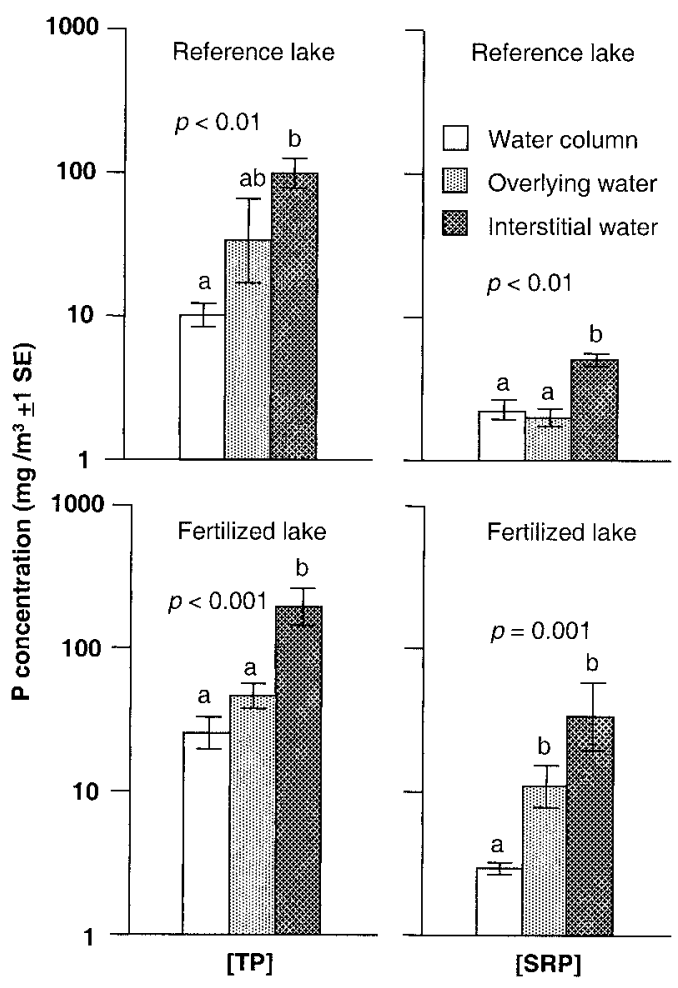

FIG. 5. Total P concentration ([TP]) and soluble reactive $P$ concentration ([SRP]) in the water column, the water immediately overlying the sediments $(\leq 1 \mathrm{~cm})$, and the sediment interstitial water in reference and fertilized lakes. Bars are geometric means averaged over the epilimnion and metalimnion to a depth of 5 m. $p$-values are for the overall ANOVA. Within a single graph, bars with the same letter above them are not significantly different $(p<0.05$, Tukey's HSD test). 
of the filamentous algal mat with increased light. The thicker mat may have led to increased self-shading and thicker boundary layers for nutrient uptake in high light versus low light treatments. Such effects may have dampened the response of epixylon to fertilization at high light levels.

The results of the laboratory experiment (Fig.1), the depth-specific shapes of P-I curves (Fig. 3), and the relationship between in situ light and production (Fig. 4) all indicated that light was more important than water-column nutrients in regulating epipelic production. At $1.5 \mathrm{~m}$ in both lakes, the relationship between light and primary production was linear over the range of incubation light intensities (Fig. 3). This linearity and lack of light-saturated primary production (the curve did not approach an asymptote to $P^{A}{ }_{\text {max }}$ ) makes estimates of $P^{A}{ }_{\text {max }}$ for $1.5 \mathrm{~m}$ suspect. Photosaturation occurred in epipelon collected from deeper areas in both lakes, and the light intensity at which saturation became apparent decreased with increased depth. We speculate that this result was caused by differences in mat structure and species composition among depths, especially the dominance at depth of slow-growing algae adapted to low light (Round 1961, Björk-Ramberg 1984, Hill 1996, Lowe 1996).

We qualitatively compared the P-I curves from the 2 lakes by estimating production at average light intensities for each site. The linear relationship between predicted production and average in situ light demonstrated that epipelic production in the fertilized lake was not higher than in the reference lake when we accounted for differences in light (Fig. 4). Although a positive fertilization response could have been counterbalanced by lower temperatures or higher numbers of grazers in the fertilized lake, the P-I curve data strongly supported the laboratory results: light, not water-column nutrients, determined epipelic productivity. This finding is consistent with in situ experiments showing that epipelic algae often respond negatively to water-column fertilization because of increased shading by phytoplankton or macrophytes (Van Raalte et al. 1976, Björk-Ramberg 1983, 1984, Björk-Ramberg and Ảnell 1985, Hansson 1988, 1992).

\section{Local influence of substratum}

Epipelic algae can reduce nutrient diffusion from the sediment pore water to the water col- umn and, in doing so, reduce nutrient availability to phytoplankton (Carlton and Wetzel 1988, Hansson 1988, 1989). However, unless epipelic algae are $100 \%$ effective in preventing nutrient diffusion from sediment, sediment may influence water-column nutrients moreso than nondiffusing substrata such as wood or rocks. Phytoplankton chlorophyll, chlorophyll on glass slides, and water-column [TP] all were higher in buckets containing sediment compared with those with wood (Fig. 2). There are at least 2 possible mechanisms for the observed patterns: 1) sediment diffuses labile nutrients to the water column that can be converted into planktonic and periphytic algal biomass; and 2) sediment, more than wood, provides algal colonizers to the water and nearby artificial substrata (Barbiero and Welch 1992, Hansson et al. 1994). Although we cannot distinguish between these mechanisms, our experiment suggests that sediment-derived nutrients become available to primary producers growing near, but not on, sediment.

We did not detect a fertilization effect on glass-slide or phytoplankton chlorophyll in buckets with sediment, but we did with wood. Thus, the substratum effect overwhelmed the fertilization treatment. This pattern was the same as observed for primary production of periphyton growing directly on the substrata (Fig. 1). We saw similar indirect influences of sediment in a mesocosm experiment in nearby Central Long Lake. Chlorophyll on mesocosm walls was highest near the sediment, independent of nutrient treatment and light availability, in both fertilized and control mesocosms (Blumenshine et al. 1997). The influence of sediment nutrients on adjacent primary producers was probably exaggerated in both the mesocosm and bucket experiments as a result of container effects that reduced dilution by the water column. Nevertheless, if fluxes of labile nutrients or viable algal cells occur between different substrata, placing non-nutrient diffusing or artificial substrata near nutrient-rich sediment may affect the outcome of experiments.

In conclusion, nutrient enrichment is one of the most common anthropogenic stresses on lakes, and limnologists have repeatedly demonstrated the strong relationship between $\mathrm{P}$ loading and phytoplankton biomass (Dillon and Rigler 1974, Schindler 1978). Ecologists increasingly recognize the importance of periphyton in 
food webs and nutrient cycles in lakes and streams (Minshall 1978, Bothwell 1993, France 1995, Hecky and Hesslein 1995, Lamberti 1996, Lodge et al. 1998). However, our understanding of the effect of eutrophication on periphyton in lakes lags far behind that for phytoplankton (Ennis 1975, Shortreed et al. 1984, Catteneo 1987). Our experiments suggest that periphyton response to fertilization is complex and dependent on substratum. Periphyton on wood increased production during fertilization, but periphyton on sediment did not. Furthermore, areal epipelic production rates were $10 \times$ higher than those of epixylon. If these patterns are common in other lakes in which organic sediment is a substantial proportion of benthic habitat, then extrapolating from hard substrata will underestimate benthic primary production and overestimate periphyton response to fertilization.

\section{Acknowledgements}

We thank D. Morrow, R. Affolter, S. Parrot, C. O'Reilly, N. Voichick, K. Watson, N. Weede, and L. Wood for field and technical help. W. Hill and 2 anonymous reviewers helped improve the manuscript. We thank S. Carpenter for providing water-column nutrient data, and M. Berg, J. Runde, and R. Hellenthal for facilitating research at the University of Notre Dame Environmental Research Center (UNDERC). This paper is a contribution of UNDERC. The National Science Foundation provided support through a graduate research traineeship (NSFGER 94-52655) and a Doctoral Dissertation Improvement Grant (NSFDEB 95-20663) to YV and through grant NSFDEB 91-07569 to DML. YV was also supported by fellowships from the Luce Foundation and from the Bayer Foundation through the Center for Environmental Research and Technology at the University of Notre Dame.

\section{Literature Cited}

BARbiero, R. P., AND E. B. Welch. 1992. Contribution of benthic blue-green algal recruitment to lake populations and phosphorus translocation. Freshwater Biology 27:249-260.

BJÖRK-RAMBERG, S. 1983. Production of epipelic algae before and during lake fertilization in a subarctic lake. Holarctic Ecology 6:349-355.

BJÖRK-RAMBERG, S. 1984. Species composition and biomass of an epipelic algal community in a subarc- tic lake before and during lake fertilization. Holarctic Ecology 7:195-201.

BJÖRK-RAMBERG, S., AND C. ÅNELl. 1985. Production and chlorophyll concentration of epipelic and epilithic algae in fertilized and nonfertilized subarctic lakes. Hydrobiologia 126:213-219.

Blumenshine, S. C., Y. VADEBONCOEUR, D. M. LODGE, K. L. CotTingham, AND S. E. KNight. 1997. Benthic-pelagic links: responses of benthos to watercolumn nutrient enrichment. Journal of the North American Benthological Society 16:466-479.

BorCHARDT, M. A. 1996. Nutrients. Pages 183-227 in R. J. Stevenson, M. L. Bothwell, and R. L. Lowe (editors). Algal ecology: freshwater benthic ecosystems. Academic Press, San Diego.

BothWELL, M. L. 1993. Artificial streams in the study of algal/nutrient dynamics. Pages 327-333 in G. A. Lamberti and A. D. Steinman (editors). Research in artificial streams: applications, uses, and abuses. Iournal of the North American Benthological Society 12:313-384.

BURKHOLDER, J. M. 1996. Interactions of benthic algae with their substrata. Pages 253-297 in R. J. Stevenson, M. L. Bothwell, and R. L. Lowe (editors). Algal ecology: freshwater benthic ecosystems. Academic Press, San Diego.

BurKholder, J. M., AND R. G. Wetzel. 1990. Epiphytic alkaline phosphatase on natural and artificial plants in an oligotrophic lake: re-evaluation of the role of macrophytes as a phosphorus source for epiphytes. Limnologv and Oceanography 35: 736-747.

Carlton, R. G., And R. G. Wetzel. 1988. Phosphorus flux from lake sediments: effect of epipelic algal oxygen production. Limnology and Oceanography 33:562-570.

Carpenter, S. R., D. L. Christensen, J. J. Cole, K. L. Cottingham, X. He, J. R. Hodgson, J. F. KitchEll, S. E. KNight, M. L. Pace, D. M. Post, D. E. SCHINDLER, AND N. VOICHICK. 1995. Biological control of eutrophication in lakes. Environmental Science and Technology 29:784-786.

Carpenter, S. R., J. J. Cole, J. F. Kitchell, And M. L. PACE. 1998. Impact of dissolved organic carbon, phosphorus, and grazing on phytoplankton biomass and production in experimental lakes. Limnology and Oceanography 43:73-80.

CARPENTER, S. R., AND J. F. Kitchell. 1993. Experimental lakes, manipulations, and measurements. Pages 15-25 in S. R. Carpenter and J. F. Kitchell (editors). The trophic cascade in lakes. Cambridge University Press, Cambridge, UK.

Carpenter, S. R., J. F. Kitchell, K. L. Cottingham, D. E. Schindler, D. L. Christensen, D. M. Post, AND N. VOICHICK. 1996. Chlorophyll variability, nutrient input, and grazing: evidence from whole-lake experiments. Ecology 77:725-735.

Carpenter, S. R., J. Morrice, P. A. Saranno, J. J. El- 
Ser, N. A. MacKay, And A. St. Amand. 1993. Primary production and its interactions with nutrients and light transmission. Pages 225-251 in S. R. Carpenter and J. F. Kitchell (editors). The trophic cascade in lakes. Cambridge University Press, Cambridge, UK.

Cattaneo, A. 1987. Periphyton in lakes of different trophy. Canadian Journal of Fisheries and Aquatic Sciences 44:296-303.

Christensen, D. L., S. R. Carpenter, K. L. CottingHAM, S. E. KNIGHT, J. P. LeBouton, D. E. SCHINDLer, N. Voichick, J. J. COle, AND M. L. PACE. 1996. Pelagic responses to changes in dissolved organic carbon following division of a seepage lake. Limnology and Oceanography 41:553-559.

Cottingham, K. L., AND S. R. CARPENTER. 1998. Population, community and ecosystem variates as ecological indicators: phytoplankton responses to whole-lake enrichment. Ecological Applications 8: 508-530.

Cottingham, K. L., S. E. Knight, S. R. Carpenter, J. J. Cole, M. L. PaCe, And A. E. Wagner. 1997. Response of phytoplankton and bacteria to nutrients and zooplankton: a mesocosm experiment. Journal of Plankton Research 19:995-1010.

CoUCH, C. A., AND J. L. MeYER. 1992. Development and composition of the epixylic biofilm in a blackwater river. Freshwater Biology 27:43-51.

Dillon, P. J., AND F. H. Rigler. 1974. The phosphoruschlorophyll relationship in lakes. Limnology and Oceanography 19:767-773.

ENNIS, G. L. 1975. Distribution and abundance of benthic algae along phosphate gradients in Kootenay Lake, British Columbia. Verhandlungen der Internationalen Vereinigung für theoretishe und angewandte Limnologie 19:562-570.

FAIRCHILD, G. W., R. L. LOWE, AND W. B. RICHARDSON. 1985. Algal periphyton growth on nutrient-diffusing substrates: an in situ bioassay. Ecology 66: 465-472.

FAIRCHILD, G. W., AND J. W. SHERMAN. 1993. Algal periphyton response to acidity and nutrients in softwater lakes: lake comparisons vs. nutrient enrichment approaches. Journal of the North American Benthological Society 12:157-167.

FALKOWSKI, P. G., AND J. LAROCHE. 1991. Acclimation to spectral irradiance in algae. Iournal of Phycology 27:8-14.

FRANCE, R. L. 1995. Differentiation between littoral and pelagic food webs in lakes using stable carbon isotopes. Limnology and Oceanography 40: 1310-1313.

Hagerthey, S. E., AND W. C. KeRfoOt. 1998. Groundwater flow influences the biomass and nutrient ratios of epibenthic algae in a north temperate seepage lake. Limnology and Oceanography 43: 1227-1242.

HANSSON, L.-A. 1988. Effects of competitive interac- tions on the biomass development of planktonic and periphytic algae in lakes. Limnology and Oceanography 33:121-128.

HANSSON, L.-A. 1989. The influence of a periphytic biolayer on phosphorus exchange between substrate and water. Archiv für Hydrobiologie 115: 21-26.

HANSSON, L.-A. 1990. Quantifying the impact of periphytic algae on nutrient availability for phytoplankton. Freshwater Biology 24:265-273.

HANSSON, L.-A. 1992. Factors regulating periphytic algal biomass. Limnology and Oceanography 37: 322-328.

Hansson, L.-A., L. G. Rudstam, T. B. Johnson, P. SORANNO, AND Y. AlLEN. 1994. Patterns in algal recruitment from sediment to water in a dimictic, eutrophic lake. Canadian Journal of Fisheries and Aquatic Sciences 51:2825-2833.

Hecky, R. E., AND R. H. HessLein. 1995. Contributions of benthic algae to lake food webs as revealed by stable isotope analysis. Iournal of the North American Benthological Society 14:631-653.

HENLEY, W. J. 1993. Measurement and interpretation of photosynthetic light-response curves in algae in the context of photoinhibition and diel changes. Journal of Phycology 29:729-739.

HILL, W. 1996. Effects of light. Pages 121-148 in R. J. Stevenson, M. L. Bothwell, and R. L. Lowe (editors). Algal ecology: freshwater benthic ecosystems. Academic Press, San Diego.

HiLl, W. R., AND H. L. Boston. 1991. Community development alters photosynthesis-irradiance relations in stream periphyton. Limnology and Oceanography 36:1375-1389.

HILL, W. R., AND A. W. KNIGHT. 1988. Nutrient and light limitation of algae in two northern California streams. Journal of Phycology 24:125-132.

HiLl, W. R., M. G. RYON, AND E. M. SCHILling. 1995. Light limitation in a stream ecosystem: responses by primary producers and consumers. Ecology 76:1297-1309.

HiLton, J. 1985. A conceptual framework for predicting the occurrence of sediment focusing and sediment redistribution in small lakes. Limnology and Oceanography 30:1131-1143.

Hilton, J., J. P. Lishman, AND P. V. Allen. 1986. The dominant mechanisms of sediment distribution and focusing in a small, eutrophic, monomictic lake. Limnology and Oceanography 31:125-133.

Holm-Hansen, O. 1978. Chlorophyll a determination: improvements in methodology. Oikos 30:438-447.

JAMES, W. F., AND J. W. BARKO. 1990. Macrophyte influences on the zonation of sediment accretion and composition in a north-temperate reservoir. Archiv für Hydrobiologie 120:129-142.

KAIRESAlO, T. 1980. Comparison of in situ photosynthetic activity of epiphytic, epipelic and plankton- 
ic algal communities in an oligotrophic lake, southern Finland. Journal of Phycology 16:57-62.

KIRK, J. T. O. 1994. Light and photosynthesis in aquatic ecosystems. 2nd edition. Cambridge University Press, Cambridge, UK.

Krause-Jensen, D., AND K. SAnd-Jensen. 1998. Light attenuation and photosynthesis of aquatic plant communities. Limnology and Oceanography 43: 396-407.

LAMberti, G. A. 1996. The role of periphyton in benthic food webs. Pages 533-572 in R. J. Stevenson, M. L. Bothwell, and R. L. Lowe (editors). Algal ecology: freshwater benthic ecosystems. Academic Press, San Diego.

LodGe, D. M., S. C. Blumenshine, AND Y. VAdEbONCOEUR. 1998. Insights and application of largescale, long-term ecological observations and experiments. Pages 202-235 in W. J. Resetarits and J. Bernardo (editors). Experimental ecology: issues and perspectives. Oxford University Press, Oxford, UK

Loeb, S. L., J. E. Reuter, AND C. R. Goldman. 1983. Littoral zone production of oligotrophic lakes: the contributions of phytoplankton and periphyton. Pages 161-167 in R. G. Wetzel (editor). Periphyton. Junk, The Hague, The Netherlands.

LOWE, R. L. 1996. Periphyton patterns in lakes. Pages 57-76 in R. J. Stevenson, M. L. Bothwell, and R. L. Lowe (editors). Algal ecology: freshwater benthic ecosystems. Academic Press, San Diego.

Marker, A. F. H., C. A. Crowther, AND F. J. M. GUNN. 1980. Methanol and acetone as solvents for estimation of chlorophyll $a$ and phaeopigments by spectrophotometry. Archiv für Hydrobiologie, Ergebnisse der Limnologie 14:52-69.

MARKS, J. C., AND R. L. LOWE. 1993. Interactive effects of nutrient availability and light levels on the periphyton composition of a large oligotrophic lake. Canadian Journal of Fisheries and Aquatic Sciences 50:1270-1278.

Mazumder, A., W. D. TAYlor, D. J. McQueEn, AND D. R. S. LEAN. 1989. Effects of nutrients and grazers on periphyton phosphorus in lake enclosures. Freshwater Biology 22:405-415.

MCBRIDE, G. B. 1992. Simple calculation of daily photosynthesis by means of five photosynthesis-light equations. Limnology and Oceanography 37: 1796-1808.

MinshaLL, G. W. 1978. Autotrophy in stream ecosystems. BioScience 28:767-771.

Newman, J. A., J. Bergelson, and A. Grafen. 1997. Blocking factors and hypothesis tests in ecology: is your statistics test wrong? Ecology 78:13121320.

NILSSON, P., B. JÖNSSON, I. LINDSTROM SWANBERG, AND K. SUNDBÄCK. 1991. Response of a marine shallow-water sediment system to an increased load of inorganic nutrients. Marine Ecology Progress Series 71:275-290.

Peterson, B. J., L. Deegan, J. Helfrich, J. E. Hobbie, M. Hullar, B. Moller, T. E. Ford, A. Hershey, A. Hiltner, G. Kipphut, M. A. Lock, D. M. FieBig, V. McKinley, M. C. Miller, J. R. Vestal, R. Ventullo, AND G. VolK. 1993. Biological responses of a tundra river to fertilization. Ecologv 74:653-72.

Peterson, B. J., J. E. Hobbie, A. E. Hershey, M. A. LOCK, T. E. Ford, J. R. VeStel, V. L. MCKinley, M. A. J. Hullar, M. C. Miller, R. M. Ventullo, AND G. S. VOLK. 1985. Transformation of a tundra river from heterotrophy to autotrophy by addition of phosphorus. Science 229:1383-1386.

PINCKNeY, J., AND R. G. ZINGMARK. 1993. Photophysiological responses of intertidal benthic microalgal communities to in situ light environments: methodological considerations. Limnology and Oceanography 38:1373-1383.

PregnAlL, A. M. 1991. Photosynthesis/translocation: aquatic. Pages 53-75 in D. C. Coleman and B. Fry (editors). Carbon isotope techniques. Academic Press, New York.

PRINGLE, C. M. 1990. Nutrient spatial heterogeneity: effects on community structure, physiognomy, and diversity of stream algae. Ecology 71:905920.

RASMUSSEN, J. B., AND D. J. RowAN. 1997. Wave velocity thresholds for fine sediment accumulation in lakes, and their effect on zoobenthic biomass and composition. Iournal of the North American Benthological Society 16:449-465.

Reuter, J. E., AND R. P. AXLeR. 1992. Physiological characteristics of inorganic nitrogen uptake by spatially separate algal communities in a nitrogen deficient lake. Freshwater Biology 27:227-236.

Revsbech, N. P., B. B. Jørgensen, AND O. Brix. 1981. Primary production of microalgae in sediments measured by oxygen microprofile, $\mathrm{H}^{14} \mathrm{CO}_{3}^{-}$fixation, and oxygen exchange methods. Limnology and Oceanography 26:717-730.

RosEMOND, A. D. 1993. Interactions among irradiance, nutrients, and herbivores constrain a stream algal community. Oecologia 94:585-594.

Rosemond, A. D., P. J. Mulholland, AND J. W. ElWOOD. 1993. Top-down and bottom-up control of stream periphyton: effects of nutrients and herbivores. Ecology 74:1264-1280.

RounD, F. E. 1961. Studies on bottom-living algae in some lakes of the English Lake District. Part VI. The effect of depth on the epipelic algal community. Iournal of Ecology 49:245-254.

SAND-JENSEN, K., AND J. BORUM. 1991. Interactions among phytoplankton, periphyton, and macrophytes in temperate freshwaters and estuaries. Aquatic Botany 41:137-175.

SAnd-Jensen, K., AND N. P. RevsbeCH. 1987. Photo- 
synthesis and light adaptation in epiphyte-macrophyte association measured by oxygen microelectrodes. Limnology and Oceanography 32: 452-457.

SCHINDLER, D. W. 1978. Factors regulating phytoplankton production and standing crop in the world's freshwaters. Limnology and Oceanography 23:478-486.

SCHINDLER, D. W., W. E. Frost, AND R. V. SCHMidT. 1973. Production of epilithophyton in two lakes of the Experimental Lakes Area, northwestern Ontario. Journal of the Fisheries Research Board of Canada 30:1511-1524.

SCHINDLER, D. W., R. H. Hesslein, AND M. A. TuRner. 1987. Exchange of nutrients between sediments and water after 15 years of experimental eutrophication. Canadian Journal of Fisheries and Aquatic Sciences 44 (Supplement 1):26-33.

SCHOLZ, O., AND P. I. BOON. 1993. Biofilm development and extracellular enzyme activities on wood in billabongs of south-eastern Australia. Freshwater Biology 30:359-368.

Shortreed, K. S., A. C. Costella, AND J. G. StockNER. 1984. Periphyton biomass and species composition in 21 British Columbia lakes: seasonal abundance and response to whole-lake nutrient additions. Canadian Journal of Botany 62:10221031.

Sinsabaugh, R. L., S. W. Golladay, AND A. E. LinKINS. 1991. Comparison of epilithic and epixylic biofilm development in a boreal river. Freshwater Biology 25:179-187.
SOKAL, R. R., AND F. J. RoHLF. 1981. Biometry. 2nd edition. W. H. Freeman and Company, San Francisco.

Stainton, M. P., M. J. CAPEL, AND F. A. J. Armstrong. 1977. The chemical analysis of fresh water. 2nd edition. Canadian Fisheries and Marine Service Miscellaneous Special Publication 25, Supplement A.

Stanley, D. W. 1976. Productivity of epipelic algae in tundra ponds and a lake near Barrow, Alaska. Ecology 57:1015-1024.

VADEBONCOEUR, Y., AND D. M. LODGE. 1998. Dissolved inorganic carbon sources for epipelic algal production: sensitivity of primary production estimates to spatial and temporal distribution of ${ }^{14} \mathrm{C}$. Limnology and Oceanography 43:1222-1226.

Van RaAlte, C. D., I. Valiela, AND J. M. Teal. 1976. Production of epibenthic salt marsh algae: light and nutrient limitation. Limnology and Oceanography 21:862-872.

Welch, H. E., AND J. KaLfF. 1974. Benthic photosynthesis and respiration in Char Lake. Iournal of the Fisheries Research Board of Canada 31:609-620.

WetZEL, R. G. 1983. Limnology. 2nd edition. Saunders Publishing, Philadelphia.

WYNNE, D., AND G.-Y. RHEE. 1986. Effects of light intensity and quality on the relative $\mathrm{N}$ and $\mathrm{P}$ requirement (the optimum N:P ratio) of marine planktonic algae. Journal of Plankton Research 8: 91-103.

ZAR, J. H. 1996. Biostatistical analysis. 3rd edition. Prentice Hall, Upper Saddle River, New Jersey.

Received: 8 September 1998 Accepted: 22 September 1999 